\title{
Flour of mushroom Agaricus blazei as additive functional in food of laying hens
}

\author{
Farinha do cogumelo Agaricus blazei como aditivo funcional na \\ alimentação de galinhas poedeiras
}

\begin{abstract}
FREITAS, Iolanda Silveira ${ }^{1} *$; MENDONÇA, Michele de Oliveira ${ }^{1}$; FREITAS, Izabela Silveira $^{1}$; ALMEIDA NETO, Onofre Barroca de ${ }^{2}$; FERREIRA, David Garcia $^{3}$; SALGADO, Hallef Rieger ${ }^{1}$; JESUS PAULA, Daniella Aparecida de
\end{abstract}

${ }^{1}$ Instituto Federal de Educação, Ciência e Tecnologia do Sudeste de Minas Gerais, Departamento Acadêmico de Zootecnia, Rio Pomba, Minas Gerais, Brasil

${ }^{2}$ Instituto Federal de Educação, Ciência e Tecnologia do Sudeste de Minas Gerais, Departamento de Educação, Rio Pomba, Minas Gerais, Brasil.

${ }^{3}$ Instituto Federal de Educação, Ciência e Tecnologia do Sudeste de Minas

Gerais, Departamento de Alimentos, Rio Pomba, Minas Gerais, Brasil. *Endereço

para correspondência: iolandafreitas11@gmail.com

\section{SUMMARY}

The current study aims to evaluate the zootechnical performance, quality of eggs, and the immune system of the laying hen's upon supplementing their feed with the flour of the mushroom Agaricus blazei. A total of 210 Hisex Brown ${ }^{\circledR}$ hens, 67 weeks old, were distributed in a completely randomized design with five treatments (control [0\%], 0.04\%, $0.08 \%, 0.12 \%$ and $0.16 \%$ of mushroom meal) with seven replicates and six birds per experimental unit. Were evaluated the zootechnical performance (feed intake, egg production [per day and housed], marketable egg production, egg weight and egg mass, feed conversion per dozen and egg mass, and viability);egg quality (specific weight, Haugh units, weight and percentage of components, shell thickness and yellow intensity of the egg yolks); and the hemogram (erythrogram and leukogram). Mainly, different levels of mushroom meal, were includedin laying hens feeds significantly $(p<0.05)$ egg mass and feed intake. However, the leukogram and the erythrogram remained within the reference values, indicating that the birds were healthy. The addition of different levels of Agaricus blazei flour in the laying hens feed did not promote changes in the egg quality, in the immune system, and in the zootechnical performance, except for the feed intake which reduced with the inclusion of mushroom flour and eggs mass in which the $0.07 \%$ level promoted the maximization of this parameter.

Keywords: fungi medicinal, nutrition, system imune

\section{RESUMO}

Objetivou-se avaliar a adição da farinha do cogumelo Agaricus blazei na ração de galinhas poedeiras sobre o desempenho zootécnico, a qualidade de ovos e o sistema imune. Foram utilizadas 210 galinhas Hisex Brown $^{\circledR}$, com 67 semanas de idade, distribuídas em delineamento inteiramente casualizado composto por cinco tratamentos (controle [0\%]; 0,04\%; 0,08\%; 0,12\% e $0,16 \%$ da farinha do cogumelo) com sete repetições e seis aves por unidade experimental. Foi avaliado o desempenho zootécnico (consumo de ração; produção de ovos [ave/dia e ave alojada]; produção de ovos comercializáveis; peso médio e massa de ovos; conversão alimentar por dúzia e por massa de ovos e viabilidade das aves); a qualidade dos ovos (peso específico, 
unidades Haugh, peso e porcentagem dos componentes, espessura de casca e intensidade da cor amarela das gemas); e o hemograma (eritrograma e leucograma). A inclusão de diferentes níveis de farinha de cogumelo na ração das galinhas poedeiras afetou significativamente $(\mathrm{p}<0,05)$ a massa de ovos e o consumo de ração. O leucograma e o eritrograma se mantiveram dentro dos valores de referência, indicando que as aves se encontravam saudáveis. A adição de diferentes níveis da farinha de Agaricus blazei na ração das galinhas poedeiras não promoveu alterações na qualidade dos ovos, no sistema imune nem tampouco no desempenho zootécnico, com exceção do consumo de ração que reduziu com a inclusão da farinha, e da massa de ovos em que o nível de $0,07 \%$ promoveu a maximização deste parâmetro. Palavraschave: beta-glucanas, cogumelo do sol, fungos medicinais, imunonutrição 


\section{INTRODUCTION}

In poultry, the intensive breeding system constantly faces several challenges during the life of the birds, and subsequently influences the health of the same, by sanitary, nutritional aspects, and by the stress management practices. For this, the immune system of birds needs defense tools against pathogenic microorganisms and their proliferation, which can lead to several diseases (SQUIRES, 2003).

According to Furlan; Macari (2002), the increase in the productive capacity of the birds resulted in several metabolic and management problems, evidencing the low capacity of the bird'simmune system.

Deficient nutrition and the stressful environment, as mentioned by Squires (2003), act in such a way to that the response of the animals immune system to the antigens gets reduced, making them more susceptible in developing diseases.

In recent years, studies with the use of bioactive substances extracted from specific species of basidiomycete fungi are increasing, being popularly known as medicinal mushrooms (WONG et al., 1994). These mushrooms present in their composition polysaccharides of the $\beta$-glucan group, which may be capable of stimulating the immune response of the host (MIZUNO et al., 1998).

According to Souza (2001), Agaricus blazei, also known as "sun mushroom" has aroused the attention of the researchers, because it presents high

levels of bioactive compounds, including $\beta$-D-Glucans. Those compounds, according to Daba; Ezeronye (2003), are directly related to the stimulation of the immune response, through the activation of immunocompetent cells and / or their chemical mediators.

In view of the above considerations, the objective was to evaluate the zootechnical performance, egg quality and immune system of laying hens upon being fed with the different levels of Agaricus blazei flour in the diet.

\section{MATERIAL AND METHODS}

The experiment was carried out in the poultry farming sector of the Department of Animal Science of the Federal Institute of Education, Science and Technology of the Southeast of Minas Gerais Campus Rio Pomba, lasting 84 days, with the duration being divided into three periods of 28 days each, from April to July of 2016 (Process $n^{\circ}$ 08/2016, approved by the Ethical Commission on the Use of

Animals[CEUA] of the Federal Institution of the Southeast of Minas Gerais).

A total of 210 laying hens of the Hisex Brown ${ }^{\circledR}$ lineage were used in the 67-80 week-old phase distributed in a completely randomized design with five treatments (control [0\%], 0.04\%, 0.08\%, $0.12 \%, 0.16 \%$ of the Agaricus blazei meal added to the poultry feed), with seven replicates and six birds per experimental unit.

Galvanized wire cages with two compartments, with each compartment being $0.50 \mathrm{~m}$ long, $0.44 \mathrm{~m}$ wide, and $0.40 \mathrm{~m}$ high each were employed for housing the birds. In each compartment, three birds were housed, totaling six birds per cage, in the space of $733 \mathrm{~cm}^{2}$ / bird. Further, the cages had a troughtype feeder made of PVC that covered the entire length of the cages and a nipple-type drinking fountain, with the 
association of one drinking fountain for every two experimental units.

The same commercial ration, specific to poultry in the poultry farming sector of the Federal Institute of the Southeast of Minas Gerais Campus Rio Pomba (Table 1) was provided at will, two times for day.

Table 1.Nutrient warranty levels per kilogram of feed

\begin{tabular}{|c|c|c|}
\hline Nutrient & Quantity & Unity \\
\hline Humidity (Maximum) & 130,00 & $\mathrm{~g}$ \\
\hline Metabolizable Energy (Minimum) & $2.750,00$ & kcal \\
\hline Ethereal Extract (Minimum) & 25,00 & g \\
\hline Gross Protein (Minimum) & 165,00 & $\mathrm{~g}$ \\
\hline Lysine (Minimum) & $8.000,00$ & $\mathrm{mg}$ \\
\hline Methionine (Minimum) & $3.800,00$ & $\mathrm{mg}$ \\
\hline Gross Fiber (Maximum) & 50,00 & g \\
\hline Mineral Matter (Maximum) & 160,00 & $\mathrm{~g}$ \\
\hline Calcium (Minimum / Maximum) & $40,00 / 42,00$ & $\mathrm{~g}$ \\
\hline Total Phosphorus (Minimum) & $5.500,00$ & $\mathrm{mg}$ \\
\hline Available Phosphor (Minimum) & $4.200,00$ & $\mathrm{mg}$ \\
\hline Sodium (Minimum) & $1.800,00$ & $\mathrm{mg}$ \\
\hline Copper (Minimum) & 8,00 & $\mathrm{mg}$ \\
\hline Iron (Minimum) & 32,00 & $\mathrm{mg}$ \\
\hline Iodine (Minimum) & 1,00 & $\mathrm{mg}$ \\
\hline Cobalt (Minimum) & 0,15 & $\mathrm{mg}$ \\
\hline Manganese (Minimum) & 80,00 & $\mathrm{mg}$ \\
\hline Selenium (Minimum) & 0,30 & $\mathrm{mg}$ \\
\hline Zinc (Minimum) & 66,00 & $\mathrm{mg}$ \\
\hline Vitamin A (Minimum) & $7.000,00$ & UI \\
\hline Vitamin D3 (Minimum) & $1.750,00$ & UI \\
\hline Vitamin E (Minimum) & 7,00 & UI \\
\hline Vitamin K3 (Minimum) & 1,50 & $\mathrm{mg}$ \\
\hline Vitamin B1 (Minimum) & 0,50 & $\mathrm{mg}$ \\
\hline Vitamin B2 (Minimum) & 3,85 & $\mathrm{mg}$ \\
\hline Vitamin B6 (Minimum) & 1,00 & $\mathrm{mg}$ \\
\hline Vitamin B12 (Minimum) & 6,00 & $\mathrm{mcg}$ \\
\hline Folic Acid (Minimum) & 0,30 & $\mathrm{mg}$ \\
\hline Linoleic acid & 12,5 & $\mathrm{~g}$ \\
\hline Calcium Pantothenate (Minimum) & 5,85 & $\mathrm{mg}$ \\
\hline Niacin (Minimum) & 15,00 & $\mathrm{mg}$ \\
\hline Hill (Minimum) & 300,00 & $\mathrm{mg}$ \\
\hline Biotin (Minimum) & 0,05 & $\mathrm{mg}$ \\
\hline Bacitracin Zinc & 25,00 & $\mathrm{mg}$ \\
\hline Phytase (Minimum) & 300,00 & FTU \\
\hline
\end{tabular}

Kcal = kilocalorie

$\mathrm{UI}=$ International Units

$\mathrm{mcg}=$ microgram

FTU $=$ Phytase Activity Unit 
In this basal feed the following percentages of the flour of Agaricus

blazei were added:0.00; $0.04 ; 0.08 ; 0.12$, and $0.16 \%$.

Agaricus blazei flour was added to the basal feed in a vertical mixer for 15 minutes, and subsequently, the mixture was bagged and identified. But for rendering fresh and nutritional quality ration throughout the experiment, the mixture was kept out two days before the beginning of each experimental period.

Apart from this, the maximum and minimum temperatures and the relative air humidity (RH) were monitored twice a day at 7.0 and 17.0 hours by means of digital thermo hygrometers (Incoterm ${ }^{\circledR}$ ) and ananalog dry-bulb thermo hygrometer (Incoterm $\AA$ ), positioned in the center of the shed, at the level of the back of the birds.

Additionally, 17.0 hours of light were provided daily throughout the experimental period. This light supply was controlled by an automatic watch (timer), which allows the lights to be switched on and off during the night and dawn, according to the procedure adopted on commercial farms.

With the aim of having profound knowledge regarding the addition of the flour of the mushroom Agaricus blazei in the feed of the laying hen's, following parameters were evaluated, the zootechnical performance (feed intake, egg production [per day and housed], marketable egg production, egg weight and egg mass, feed conversion per dozen and egg mass, and viability);egg quality (specific weight, Haugh units, weight and percentage of components, shell thickness and yellow intensity of the egg yolks); and the effect on the immune system through the level of leukocytes in the blood. With the exception of the last parameter, being evaluated at the end of the experiment, the other parameters (performance and quality of eggs) were measured at the end of each 28 days period, totaling three evaluations. Therefore, in the statistical analysis, except for the parameter leukocyte level in blood, the mean of the seven replicates of the three 28 days period of each parameter was used.

Further, at the end of each experimental period, the leftovers from each plot were weighed and subtracted from the amount of feed provided in order to obtain feed intake. In the case of dead birds during the period, their average consumption was deducted and corrected, obtaining the average true consumption for the experimental unit.

On the other hand, the average egg production was obtained, by computing the number of eggs produced, including broken, cracked, and abnormal eggs (eggs with soft shells and shelled eggs), expressed as a percentage of the average number of birds in the period (egg/bird/day) and on the number of birds housed at the beginning of the period (egg/bird housed).

To determine the marketable egg production, the number of broken and cracked eggs, in addition to, the eggs with soft shells and shelled eggs were deducted from total egg production in each 28-day period, followed by the estimation of the relationship between whole eggs and total eggs produced during each period.

All the eggs produced in each repetition were weighed during the last three days of each 28 days period to obtain the average weight (mean egg weight), which was further multiplied by the 
eggs/bird/day production, to obtain the total egg mass.

Feed conversion per dozen eggs was calculated, by the relation of the total feed consumption in kilograms divided by the dozen eggs produced $(\mathrm{kg} / \mathrm{dz})$, and the feed conversion per egg mass was calculated, by the feed consumption in kilograms divided by the total egg mass $(\mathrm{kg} / \mathrm{kg})$.

Further, the mortality of the birds was monitored daily so that at the end of the experimental period the bird viability rate was obtained, calculated by estimating the difference in the number of live birds and the number of dead birds, with the representation of the final result in the form of a percentage.

Additionally, the evaluation of internal and external parameters of the eggs such as specific weight, quantification of the components, Haugh units, yellow yolk intensity, and shell thickness, was performed according to the methodology adopted by Oliveira; Oliveira (2013).

The specific weight of the eggs was determined, on the 26th, 27th and 28th day of each 28 days period by immersing the whole eggs in saline solutions of different density, mainly varying from 1.055 to $1.095 \mathrm{~g} / \mathrm{cm}^{3}$, at intervals of $0.005 \mathrm{~g} / \mathrm{cm}^{3}$, duly calibrated by means of a densimeter (OM-5565, Incoterm $^{\circledR}$ ).

Subsequently, for the quantification of the components of the eggs, following parts of the egg were evaluated, the weight of the yolk, the weight of the albumen, and the weight of the eggshell. For carrying out the assessment, on the 26th, 27th, and 28th day of each period of 28 days all the whole eggs were collected, of which 28 eggs of each treatment underwent random selection, thereby selecting seven replicates of each of the four eggs.
The eggs of each repetition and of each day were individually weighed, in the balance with an accuracy of $0.001 \mathrm{~g}$. After weighing, the eggs were identified; thereby segregating broken eggs, the yolk of the egg and the albumen. The weight of the yolk of

each egg was recorded, and subsequently, the yolk was destined to the determination of the pigmentation. The weight of the albumen was obtained, by subtracting from the weight of the egg, the weight of the yolk more the weight of the bark, obtained after rinsing the bark and drying in a forced air circulation oven for 24 hours. The percentage of albumin, yolk, and peel was obtained, by dividing the weights of the respective components by the average egg weight, followed by multiplying the result by 100 .

The height of the albumen was measured using a digital caliper (100.179J Digimess $\left.{ }^{\circledR}\right)$. Haugh units were calculated using the following formula: $\mathrm{UH}=100 * \log (\mathrm{h}+7.57-1.7$ $\mathrm{W}^{0.37}$ ), where: $\mathrm{UH}=$ Haugh units; $\mathrm{h}=$ height of dense albumen $(\mathrm{mm}) ; \mathrm{W}=$ weight of the egg $(\mathrm{g})$.

Further, the thickness of the shell was measured, with the help of a digital micrometer, with the measurement being carried out after the drying of the shell (obtained after breaking the eggs [equatorial region]), and subsequently, the components of the shell were

quantified. Principally, the measurements of shell fragments were performed at both poles as well as in the middle of the egg. Moreover, the shell thickness of each repetition was determined, by the arithmetic mean of the three measurements.

With the aim of evaluating the intensity of the yellow color of the gems, the colorimetric fan of DSM $®$, old Roche, 
was employed. For carrying out the measurement, the exposure of the gem to a white surface was followed, by the visual comparison of the color of each gem, in nature, with the subsequent classification of the gem color using the fan (score from 1 to 15 , ranging from light yellow to orange). This procedure was performed, by the same three judges on each evaluation day. Each value of the intensity of pigmentation of the yolk corresponded to the average of the three values mentioned by the judges after individually evaluating each gem. Moreover, the mean of each treatment was calculated, by the average of the pigmentation scores of the egg yolks of the respective replicates.

At the end of the experimental period, blood samples were collected from three birds randomly by treatment, thereby collectinga total of 15 samples. According to the recommendation made by Zander; Mallinson (1991), the blood from birds were obtained, by puncturing the brachial vein, where the blood upon collection, was placed in glass tubes with an anticoagulant solution (EDTA $5 \%$ - ethylenediaminetetraacetic acid) and was sent to a laboratory of clinical analysis for determining the leukocyte levels in the blood of birds.

Statistical analysis were performed using the SISVAR program (FERREIRA, 2014), with the average of the three cycles of 28 days. The results were subjected, to the analysis of variance, and polynomial regression was performed for the significant parameters at the 0.05 probability level.

\section{RESULTS AND DISCUSSION}

During the experimental period, mean values of maximum and minimum temperatures of $27 \pm 3.13{ }^{\circ} \mathrm{C}$ and $16,8 \pm$ $3.24{ }^{\circ} \mathrm{C}$, respectively, were recorded. Additionally, the relative humidity of air was observed to be $71.3 \pm 4.66 \%$.

The inclusion of different levels of Agaricus blazei mushroom flour in laying hens ration affected fed significantly ( $p<0.05$ ), in particular, the egg mass and feed intake. The other parameters of zootechnical performance were not influenced ( $p>0.05)$ by the addition of flour in the poultry feed (Table 2). 
Table 2.Parameters of the zootechnical performance of laying hens fed rations with the inclusion of different levels of Agaricus blazei flour

\begin{tabular}{|c|c|c|c|c|c|c|c|}
\hline \multirow{2}{*}{ Parameters } & \multicolumn{5}{|c|}{$\begin{array}{c}\text { Levels of Inclusion of } \\
\text { Flour of Agaricus blazei (\%) }\end{array}$} & \multirow{2}{*}{$\begin{array}{l}\text { Value } \\
\mathbf{P}\end{array}$} & \multirow{2}{*}{$\begin{array}{l}\text { CV } \\
(\%)\end{array}$} \\
\hline & $\mathbf{0}$ & $\begin{array}{c}0,04 \\
\end{array}$ & 0,08 & 0,12 & 0,16 & & \\
\hline $\begin{array}{l}\text { Egg production } \\
\text { bird/housed (\%) }\end{array}$ & 89,99 & 92,97 & 91,41 & 89,77 & 88,27 & 0,1693 & 3,96 \\
\hline $\begin{array}{l}\text { Egg production } \\
\text { bird/day }(\%)\end{array}$ & 90,52 & 92,97 & 91,41 & 89,77 & 88,27 & 0,1803 & 3,97 \\
\hline $\begin{array}{l}\text { Production marketable } \\
\text { eggs }(\%)\end{array}$ & 89,95 & 92,52 & 91,18 & 89,31 & 87,59 & 0,1742 & 4,20 \\
\hline Eggs mass (g/bird/day)* & 9,01 & 9,63 & 9,39 & 9,09 & 8,91 & 0,0251 & 4,72 \\
\hline Feed intake (g/bird/day)** & 115,19 & 115,24 & 114,96 & 114,74 & 114,48 & 0,0001 & 0,25 \\
\hline $\begin{array}{l}\text { Feed conversion } \\
\text { (kg/dozen) }\end{array}$ & 1,53 & 1,49 & 1,51 & 1,54 & 1,56 & 0,2791 & 4,09 \\
\hline$(\mathrm{kg} / \mathrm{kg})$ & 2,14 & 2,01 & 2,06 & 2,13 & 2,17 & 0,0548 & 4,91 \\
\hline Viability (\%) & 97,62 & 100,00 & 100,00 & 100,00 & 100,00 & 0,4229 & 2,83 \\
\hline
\end{tabular}

*Quadratic $(\mathrm{p}=0.0116)$

** Linear $(\mathrm{p}=0.0000)$

$\mathrm{CV}=$ Coefficient of Variation $(\%)$

The feed consumption decreased linearly with the addition of mushroom levels (Figure 1) and the egg mass presented a quadratic behavior (Figure 2), being the maximum of that variable observed with the inclusion of $0.07 \%$ of Agaricus blazei flour in the ration, which reflects in a better productive performance of birds fed with this diet.

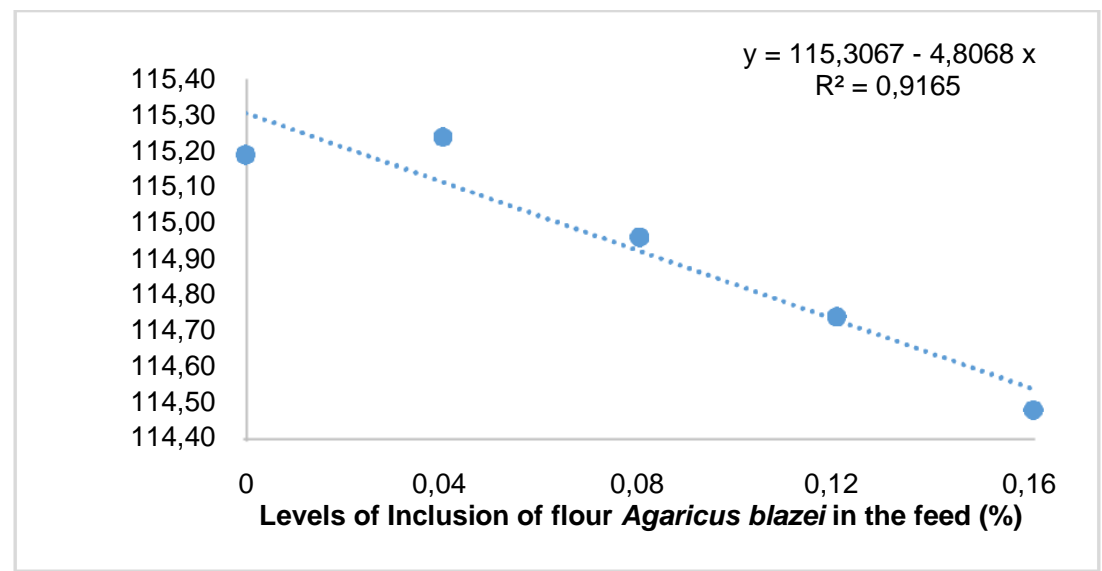

Figure 1. Effect of the inclusion level of Agaricus blazei mushroom flour on the feed intake ( $\mathrm{g} / \mathrm{bird} /$ day) of laying hens 


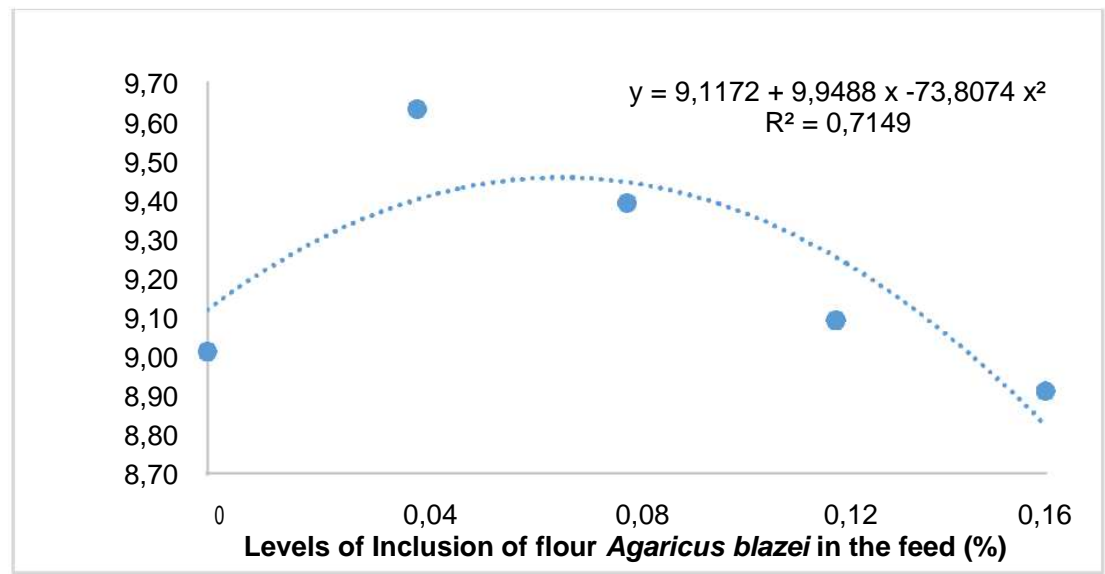

Figure 2. Effect of the inclusion level of the Agaricus blazeimushroom meal on the egg mass (g/bird/day) of laying hens

Souza (2011) evaluated the effect on the zootechnical performance of the Japanese quail upon the inclusion of different levels $(0 \%, 0.5 \%, 1 \%$, and $1.5 \%$ ) of the Ganoderma lucidum mushroom in their diet, and observed a reduction in feed intake with mushroom inclusion.

Contrastingly, the study carried out with the Agaricus blazei mushroom, in the present investigation, reveals that the feed intake decreased linearly with the addition of varying levels of the mushroom in the feeding (Figure 1). However, Netto (2018) observed no effect on performance upon including the harvest residue of the mushroom Lentinula edodes in feeding laying hens. Some factors may explain the effect of Agaricus blazei on bird performance. According to Gracher (2005), the presence of the dietary fibers in mushrooms can range from 10 to $50 \%$, based on dry weight. Further, the amount of fiber present in the mushroom may have influenced the reduction of feed intake by birds, according to Silva et al. (2002), who observed a reduction in feed intake by birds upon including the algaroba pod as a whole meal, and further related this reduction in feed intake with increase in the amount of fiber present in the feed. The mushroom Agaricus blazei presents molecules like lecithin, ergosterol, arginine, and glutamine, among others (NOVAES; NOVAES, 2005).

Possibly, the egg mass may have increased ( $\mathrm{g} / \mathrm{bird} /$ day) as a function of the proteoglycans, arginine, and glutamine present in the mushroom Agaricus blazei. In this context, Zavarizeet al. (2011) found that glutamine supplementation in laying hens ration improved the egg quality and the feed conversion.

Under normal conditions, populations of the useful and harmful intestinal microbiota are in equilibrium. However, under stressful conditions, the useful population decreases and the harmful populations proliferate, which in turn exerts a negative effect on health and animal performance (MATHEW et al., 1993).

The birds fedon Agaricus blazeiflour, even in submitted heat stress, achieved the best performance at the $0.07 \%$ level of the mushroom, suggesting that substances such as chitin, hemicellulose, glucans, mannans, galactans, and xylans present in the mushroom Agaricus blazei may have 
influenced the beneficial balance of the microbiota of the gastrointestinal tract of birds(GIBSON, 2004), which corroborates with Schott (2012) who verified the prebiotic potential of Agaricus blazei in the in vitro tests.

It has been well established that the vegetative mycelium of the fungus Agaricus blazei, has in its composition active components, constituted mainly by the polysaccharides of the $\beta$-glucan group. These substances may have been able to modulate the immune system through specific interactions with several immunocompetent cells that may have acted as stimulants of the immune response of the birds, making them resistant to the action of pathogens acquired through feeding (ITO, 1997, AZEVEDO, 2014).

Glucan potentiates cellular and humoral immunity, increasing the resistance of the host to the bacteria (SORIMACHI, 2001; OHNO, 2001; KASAI, 2004).

The inclusion of the mushroom flour in the laying hens feed did not significantly $(\mathrm{p}<0.05)$ influenced the egg quality (Table 3 ).

Table 3. Parameters of quality internal and external of eggs of hens fed diets with different levels of inclusion of Agaricus blazei flour

\begin{tabular}{|c|c|c|c|c|c|c|c|}
\hline \multirow[t]{2}{*}{ Parameters } & \multicolumn{5}{|c|}{$\begin{array}{c}\text { Levels of Inclusion of } \\
\text { Flour of Agaricus blazei }(\%)\end{array}$} & \multirow[t]{2}{*}{ Value $P$} & \multirow{2}{*}{$\begin{array}{l}\text { CV } \\
(\%)\end{array}$} \\
\hline & $\mathbf{0}$ & 0,04 & 0,08 & 0,12 & 0,16 & & \\
\hline Egg weight (g) & 59,62 & 61,61 & 61,11 & 60,25 & 60,05 & 0,0667 & 2,27 \\
\hline Weight of the yolk (g) & 15,91 & 16,40 & 16,43 & 16,38 & 16,53 & 0,2859 & 3,42 \\
\hline Percentage of Yolk (\%) & 26,70 & 26,62 & 26,89 & 27,20 & 27,53 & 0,3306 & 3,38 \\
\hline Albumen weight (g) & 38,04 & 39,40 & 38,97 & 38,08 & 37,89 & 0,1151 & 3,22 \\
\hline Percentage of albumen $(\%)$ & 63,79 & 63,94 & 63,76 & 63,19 & 63,10 & 0,3908 & 1,55 \\
\hline Shell weight (g) & 5,67 & 5,81 & 5,71 & 5,79 & 5,63 & 0,0779 & 2,35 \\
\hline Percentage of shell (\%) & 9,51 & 9,43 & 9,35 & 9,61 & 9,37 & 0,1479 & 2,24 \\
\hline Specific weight (g/cm $\left.{ }^{3}\right)$ & 1,088 & 1,088 & 1,088 & 1,089 & 1,088 & 0,3275 & 0,14 \\
\hline UnitsHaugh & 85,43 & 86,59 & 88,55 & 86,71 & 86,39 & 0,0586 & 2,16 \\
\hline Shell thickness (mm) & 0,535 & 0,543 & 0,540 & 0,545 & 0,538 & 0,3235 & 1,67 \\
\hline Yolk Color & 7,91 & 7,78 & 7,94 & 7,79 & 7,89 & 0,3368 & 2,15 \\
\hline
\end{tabular}

$\mathrm{CV}=$ Coefficient of Variation (\%)

Being Haugh units (UH) are a measure of the evaluation of the internal quality of the egg, in general, the higher the $\mathrm{UH}$ value, the better the quality of the egg. According to the Program for the Control of Quality of Eggs for Consumption, recommended by the

United States Department of Agriculture (USDA, 2000), hens eggs from this work (Table 3) are of excellent quality (AA) because they have values of Haugh units above 72 .
According to Silva (2011), the higher the specific weight, the better the peel quality being desirable to be between 1,080 to $1,088 \mathrm{~g} / \mathrm{cm}^{3}$ during the laying period. In this way, one can infer that the eggs produced in this study (Table

3 ) presented highexternal quality, which contributed to the maintenance of the internal quality, regardless of the level of inclusion of the mushroom in the hens feed. 
On the other hand, Hwang et al. (2012) when added different levels $(0,0.25$ and $0.5 \%$ ) of Lentinula edodes mushroom in the laying hens feed, observed that mushroom supplementation of up to $0.5 \%$,positively affected the egg quality. However, Netto (2018) and Muži ćet al. (2005) did not observe the effect on egg quality of laying hens supplemented with Lentinula edodes mushroom.

In the present study, the inclusion of the Agaricus blazei mushroom meal in the hen's ration did not cause damage to the internal or external quality of the eggs, with supplementation of up to $0.16 \%$ of Agaricus blazei in poultry feed.

Further, no significant difference (p> 0.05 ) was observed for any of the leukogram parameters, indicating that in this work the addition of different levels of Agaricus blazei flour (0.04\%, $0.08 \%$, $0.12 \%$, and $0.16 \%$ ) in the feed did not influence the cells of the immune system of the birds (Table 4).

The values of the leukogram parameters (leukocytes, heterophils, eosinophils, basophils, lymphocytes and monocytes) and erythrogram: red blood cells, hemoglobin, hematocrit (\%), V.C.M $(\mu 3)$ and C.H.C.M $(\%)$ are within the reference values for birds (Table 4), showing no anomaly, indicating that the birds were healthy. The erythrocyte indices provide additional information for the erythrogram, which are calculated by the values of red blood cell, hematocrit, and hemoglobin. The mean corpuscular volume (MCV), which characterizes erythrocyte size and mean corpuscular hemoglobin (CHCM), expresses the amount of hemoglobin per erythrocyte (CAMPBELL, 1994; CLARCK et al., 2009).

Although the immunity blood parameters of the birds were not significantly influenced ( $p>0.05$ ), it is important to emphasize that heterophile levels (\%) were above the reference value ( $1-13 \%$ - Table 4$)$, which may suggest that the hens were under stress.

Additionally, the heterophile: lymphocyte ratio increased with the inclusion of mushroom in the feed.

On a similar note, Macari et al. (2002) pointed out that birds, increase the release of corticotrophic hormones when kept under conditions of stress promotion. As a result, the surrounding lymphocytes decreases and consequently the heterophile: lymphocyte ratio increases.

At the time of collection of the blood, for the accomplishment of the hemogram of the birds, $28.6^{\circ} \mathrm{C}$ was the maximum temperature registered inside the shed. According to Borges (2001), the blood system of birds, for being sensitive to temperature variations, is an important indicator of stressors. Additionally, Borges et al. (2003) found that for broiler chickens from 42 to 44 days of age, the progressive increase of the ambient temperature causes a decrease in the number of circulating lymphocytes.

The heterophile: lymphocyte relationship may get influenced by several factors such as the physiological status of the bird, the presence of infectious agents, the presence of people (GROSS and SIEGEL, 1983) beyond individual each bird variability (SANTOS et al., 2013). In the case of collection made by people, strangers to the birds, socializing may also have influenced the results. Similarly, as per Cïruleet al. (2012), the stress due to containment may cause changes in hematological parameters.

Fanhani et al. (2016) when evaluated the supplementation of Agaricus blazei in the diet of broilers, observed a lack of stimulation in the production of lymphocytes. The percentage of 
heterophils and monocytes were also below standard.

Further, upon estimating the effect of the inclusion of the mushroom Ganoderma lucidum on the Japanese quail feed, Souza (2011) found that the level of $1.5 \%$ of the mushroom in the feed was the one which showed the lowest heterophile: lymphocyterelation, thereby leading to lower stress level in the birds. 
Table 4.Blood parameters of laying hens fed on diets with different inclusion levels of Agaricus blazei flour

\begin{tabular}{|c|c|c|c|c|c|c|c|c|}
\hline \multirow[t]{2}{*}{ Parameters } & \multirow{2}{*}{$\begin{array}{c}\text { Reference } \\
\text { values }\end{array}$} & \multicolumn{5}{|c|}{$\begin{array}{c}\text { Levels of Inclusion of } \\
\text { Flour of Agaricus blazei }(\%)\end{array}$} & \multirow[t]{2}{*}{ Value $P$} & \multirow[t]{2}{*}{ CV $(\%)$} \\
\hline & & $\mathbf{0}$ & 0,04 & 0,08 & 0,12 & $\mathbf{0 , 1 6}$ & & \\
\hline Blood cells (millions) & $2,0-3,5$ & 2,44 & 2,38 & 2,60 & 2,71 & 2,85 & 0,7312 & 17,84 \\
\hline Hemoglobin (g\%) & $7-13$ & 10,37 & 10,03 & 11,00 & 11,63 & 11,13 & 0,7208 & 14,04 \\
\hline Hematocrit (\%) & $25-37$ & 31,33 & 30,10 & 32,96 & 34,60 & 33,73 & 0,7917 & 14,96 \\
\hline V.C.M $(\mu 3)$ & $85-180$ & 128,37 & 126,47 & 126,67 & 127,60 & 119,97 & 0,4740 & 4,74 \\
\hline C.H.C.M (\%) & $22-35$ & 33,07 & 33,37 & 33,37 & 33,57 & 33,17 & 0,9317 & 2,26 \\
\hline Leukocytes $\left(\mathrm{mm}^{3}\right)$ & $\begin{array}{l}9000- \\
30000\end{array}$ & 14433,33 & 16933,33 & 18500,00 & 15400,00 & 21666,67 & 0,5358 & 31,14 \\
\hline Eosinophils (\%) & Até 5 & 3,67 & 2,67 & 2,33 & 3,67 & 3,33 & 0,6912 & 44,38 \\
\hline Monocytes $\left(\mathrm{mm}^{3}\right)$ & - & 890,00 & 1050,00 & 1566,67 & 1042,00 & 1353,33 & 0,5131 & 42,98 \\
\hline Monocytes (\%) & Até 8 & 6,00 & 6,33 & 8,00 & 6,67 & 6,67 & 0,5962 & 23,01 \\
\hline Heterofilos (\%) & $1-13$ & 14,00 & 16,00 & 17,67 & 16,00 & 18,00 & 0,8441 & 29,02 \\
\hline Lymphocytes (\%) & $60-85$ & 76,00 & 75,00 & 71,67 & 73,67 & 72,00 & 0,8171 & 7,12 \\
\hline Lymphocytes $\left(\mathbf{m m}^{3}\right)$ & - & 7069,00 & 12728,67 & 13163,00 & 11325,00 & 15563,33 & 0,2792 & 37,28 \\
\hline $\begin{array}{l}\text { Relationship } \\
\text { Heterofilo:Lymphocyte }\end{array}$ & - & 0,12 & 0,21 & 0,25 & 0,22 & 0,26 & 0,4285 & 45,86 \\
\hline
\end{tabular}

$\mathrm{CV}=$ Coefficient of Variation (\%) 
In the present investigation, the addition of different levels of the Agaricus blazei mushroom meal in the laying hens ration did not promote changes in the egg quality, in the immune system, and in the zootechnical performance, except for the feed intake that reduced with the inclusion of flour, and of the mass of eggs in which the $0.07 \%$ level promoted the maximization of this parameter.

\section{REFERENCES}

\section{AZEVEDO, R.S. Caracterização} físico-química e microbiológica no processo da compostagem na produção do cogumelo Agaricus blasiliense e a utilização do composto de Pleurotus sp. na suplementação da ração de frango de corte . 2004. 115p. Tese (Doutorado em Ciências dos alimentos) - Universidade Federal de Lavras, Lavras.

BORGES, S.A. Balanço eletrolítico e sua interrelação com o equilíbrio ácido-base em frangos de corte submetidos a estresse calórico. 2001. 97p. Tese(Doutorado em Zootecnia) Faculdade de Ciências Agrárias e Veterinária, Universidade Estadual Paulista, Jaboticabal.

BORGES, S.A.; MAIORKA, A.; SILVA, A. V. F. Fisiologia do estresse calórico e a utilização de eletrólitos de frangos de corte. Ciência Rural,Santa Maria, v.33, n.5, p. 975-981, 2003.

CAMPBELL, T.W. Hematology In: RITCHIE, B.W.; HARRISON, G.J.; HARRISON L.R. Avian medicine: principles and application. Lake Worth: Wingers Publishing, p. 176-198, 1994.
CÏRULE, D.; KRAMA, T.; VRUBLEVSKA, J.; RANTALA, M.J; KRAMS, I. A rapid effect of handling on counts of white blood cells in a wintering passerine bird: a more practical measure of stress. Journal of Ornithology, Heidelberg, v.153, p.161166, 2012.

CLARCK, P.; BOARDMAN, W.; RAIDAL, S. Atlas of clinical avian hematology. Oxford: Blackwell Publishing, p.184, 2009.

DABA, A.S.; EZERONYE, U.O. Anticancer effect of polysaccharides isolated from higher basidiomycetes mushrooms. African Journal of Biotechnology, v.2, n.12, p.672-678, 2003.

FANHANI, J.C.; MURAKAMI, A.E.; GUERRA, A.F.Q.G.; NASCIMENTO, G.R.; PEDROSO, R.B.; ALVES, M.C.F. Effect of Agaricus blazei in the diet of broiler chickens on immunity, serum parameters and antioxidant activity.Semina: Ciências Agrárias, Londrina, v.37, n.4, p.2235-2246, 2016.

FERREIRA, D.F. SISVAR: Guide for its Bootstrap procedures in multiplecomparisons. Ciência e Agrotecnologia, v.38, n.2, p.109-112, 2014.

FURLAN, R.L.; MACARI, M. Termorregulação. In: MACARI, M.; FURLAN, R. L.; GONZALES, E. Fisiologia aviária aplicada a frangos de corte. 2. Ed. Jaboticabal: UNESP, FUNEP, p.209-230, 2002.

GIBSON, G. R.; MCCARTNEY, A. L.; RASTALL, R. A. Prebiotics and resistance to gastrointestinal infections. 
British Journal of Nutrition, London, 93: 31-34, 2004.

GRACHER, A.H.P. Caracterização estrutural de polissacarídeos obtidos do corpo de frutificação de Ganoderma multiplicatum. 2005. 80

f. Dissertação (Mestrado em Ciências Bioquímicas), Universidade Federal do Paraná, Curitiba.

GROSS, W.B.; SIEGEL, H.S. Evaluation of heterophil/lymphocyte ratio as a measure of stress in chickens. Avian Diseases, v.27, n.4, p.972-979, 1983.

HWANG, J.A.; HOSSAIN, M.E.; YUN, D.H.; MOON, S.T.; KIM, G.M.; YANG, C.J. Effect of shiitake [Lentinula edodes (Berk.) Pegler] mushroom on laying performance, egg quality, fatty acid composition and cholesterol concentration of eggs in layer chickens. Journal of Medicinal Plants, v.6, n.1, p.146-153, 2012.

ITO, H. et al. Antitumor effects of a new polysaccharide-protein complex (ATOM) prepared from Agaricus blazei (Iwade strain 101) "Himematsutake" and its mechanisms in tumor-bearing mice. Anticancer Research, Athens, v.17, n.1, p.277-284,1997.

KASAI, H.; HE, L.M.; KAWAMURA M.; YANG P.T.; DENG X.W.; MUNIKANTA M. et al. IL-12 Production Induced by Agaricus blazei Fraction $\mathrm{H}(\mathrm{ABH})$ Involves Toll-like Receptor (TLR). Evidence based Complement Alternative Medicine, v.1, n.3, p.259-267, 2004.

MACARI, M. et al. Fisiologia aviária aplicadas a frangos de corte. Campinas: FACTA, p.375, 2002.
MATHEW, A.G. et al. Effect of galactan on selected microbial populations and $\mathrm{pH}$ and volatile fatty acids in the ileum of the weanling pig. Journal of Animal Science, Savoy, v.71, n.6, p.1503-1509, 1993.

MIZUNO, M.; MORIMOTO, M.; MINATO, K. et al. Polysaccharides from Agaricus blazei stimulate lymphocyte T-cell subsets in mice. Bioscience, Biotechnology and Biochemistry, v.62, n.2, p.434-437, 1998.

MUŽI Ć,S.;JANJEČIĆ, Z.;MESARIĆ, M.;SVALINA, K. Cholesterol content and quality of eggs from hens fed feed mixture supplemented with Lentinus edodes mushroom. Stockbreeding, v.59, p.271-279, 2005.

NETTO, R.G.F. Resíduo de colheita de shiitake (Lentinula edodes (berk.) pegler) na alimentação de frangos de corte e poedeiras comerciais. 2018. 68p. Dissertação (Mestrado em Zootecnia) - Faculdade de Medicina Veterinária e Zootecnia, Universidade Estadual Paulista, Botucatu.

NOVAES,M.R.C.G.; NOVAES,L.C.G. Fármaco-nutrientes em cogumelos comestíveis Agaricales e outros basidiomicetos. Revista Brasileira de Nutrição Clínica , v.20, n.3, p.181187,2005 .

OHNO, N.; FURUKA, W.A.M.; MIURA, N.N.; ADACHI, Y.; MOTOI, M.; YADOMAE, T. Antitumor beta glucan from the cultured fruit body of Agaricus blazei. Biological and Pharmaceutical Bulletin, v.24, p.820828, 2001. 
OLIVEIRA, B.L.; OLIVEIRA, D.D. Qualidade e tecnologia de ovos. Lavras: Editora UFLA (Universidade Federal de Lavras), 2013. p.223. SANTOS, S.C.S; MEYER, R.; COSTA, M.F.D. Variety of haematological parameters of monthly blood donor dogs. Revista de CiênciasMédicas e Biológicas , v.12, p.472-477, 2013.

SCHOTT, E.; HEYDER, C.D.T.; PEREIRA, E.M.; OURIQUES, M.M.; ROSA, H.H.; FURLAN, S.A.; GERN, R.M.M. Effect of polysaccharides extracted from Pleurotusostreatus and Agaricus blazei on growth of probiotic bacteria. Journal of International Scientific Publications: Agriculture Food, Bulgaria, v.1, 2013.

SILVA, J.H.V. et al. Farinha Integral da Vagem de Algaroba (Prosopisjuliflora (Sw.) D.C.) na alimentação de codornas japonesas. Revista Brasileira de Zootecnia, v.31, n.4, p.1789-1794, 2002.

SILVA, R.C.F. Desempenho e qualidade de ovos de galinhas infectados por Mycoplasmasynoviae. Niterói: Universidade Federal Fluminense, 2011. 76 f. Tese (Doutorado em Medicina Veterinária) Universidade Federal Fluminense, 2011.

SORIMACHI, K.; AKIMOTO, K.; IKEHARA, Y.; INAFUKU, K.; OKUBO, A.; YAMAZAKI, S.

Secretion of TNF-alpha, IL-8 and nitric oxide by macrophages activated with Agaricus blazei Murill fractions in vitro. CellStructureandFunction, v.26, p.103-108, 2001.

SOUZA, B.M. Os efeitos terapêuticos de Agaricus blazei para a saúde humana. Centro Universitário de Brasília, Faculdade de Ciências da Saúde, Monografia, Brasília, 2001.

SOUZA, C. Desempenho produtivo de codornas japonesas (Coturnixcoturnix japonica) alimentadas com diferentes níveis de Ganoderma lucidum na ração . Universidade Tecnológica Federal do Paraná, Monografia, Dois Vizinhos, 2011.

\section{SQUIRES, J.E. Applied Animal}

Endocrinology. Cambridger: GABI publishing, p. 250, 2003.

USDA.United States Department of Agriculture. Egg- Grading Manual, USA, 2000.

WONG, C.K.; LEUNG, K.N.; FUNG, K.P. et al. Immunomodulatory and antitumor polysaccharides from medicinal plants. Journal of International Medicinal Research, v.22, n.6, p.299312, 1994.

ZAVARIZE, K.C.; SARTORI, J.R.; PEZZATO, A.C. et al. Glutamina na dieta de poedeiras leves submetidas ao estresse pelo calor e à termoneutralidade. Ciência Animal Brasileira, v.12, p.400-406, 2011.

ZANDER, D.V.; MALLINSON, E. T. Principles of disease Prevention: diagnosis and control. In: Calnek, B. W.; BARNES, H. J.; REID, W. M. et al. Diseases of poultry. 9.ed. EUA: Iowa State University Press, p.3-44, 1991. 